\title{
EFFECT OF BLACK GRANITE BASIN ON THE PERFORMANCE OF A SINGLE SLOPE SOLAR STILL
}

\author{
El-Sheikh, I. H.*
}

\section{ABSTRACT}

The aim of this research work is to study the effect of granite basin in solar still and thus enhance the productivity of fresh water. Two single sloped solar still was designed, installed and tested at the Agricultural Engineering Department, Faculty of Agriculture, Suez Canal University, Ismailia Governorate, Egypt (latitude angle of $30.62^{\circ} \mathrm{N}$, Longitude angle of $32.27^{\circ} \mathrm{E}$, and mean altitude above the sea level of $5 \mathrm{~m}$ ). Two different solar still basins were functioned during this research. One basin is constructed of rectangular black granite and the other is made up of galvanized iron sheet. The two solar stills are covered with clear glass sheet ( $3 \mathrm{~mm}$ thick) with an inclination angle of $31^{\circ}$. Comparison of the productivity of the granite and the conventional solar still, the productivity of the distilled water was enhanced for black granite basin solar still as compared with galvanized iron basin solar still. The productivity of the granite basin solar still was $2430 \mathrm{ml} \mathrm{m}^{-2} \mathrm{day}^{-1}$, whilst the productivity of the galvanized iron basin still is $1928 \mathrm{ml} \mathrm{m}^{-2}$ day $^{-1}$. Consequently, granite basin increased the productivity of fresh water by $20.6 \%$ as compared with the galvanized iron sheet basin.

Keywords: single slope solar still-Granite basin-galvanized iron basin

\section{INTRODUCTION}

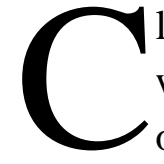
lean water is a basic human necessity, and without water the life will be impossible. Supplying fresh and healthy water is still one of the major problems in different parts of the world especially in arid remote areas (Tiwari, 2003). Sources of fresh water are the great oceans and seas that can be desalinated by various methods including solar energy. Most existing desalination plants use fossil fuel as a source of energy. Although a few techniques such as multi-effect evaporation, multi-stage flash distillation, thin film distillation, vapor compression,

*Associate Prof. of Agric. Eng. Dep., Fac. of Agric., Suez Canal Univ., 41522 Ismailia, Egypt. 
reverse osmosis and electro dialysis are energy intensive and operating cost is high. These technologies are expensive, however, for the production of small amount of fresh water. The direct use of solar energy represents a promising option for eliminating the major operating cost. Solar distillation can provide the most attractive solution for those areas where plenty of solar energy is available and water demand is not too much. Solar still can be used for producing drinking water with a low cost and maintenance, but the problem of this device is the low productivity (Duffie and Beckman, 2006). The basin-type solar stills are the most popular solar distillation systems from a technical standpoint. Different techniques were used to enhance the output of the stills. Nijmeh et al. (2005) studied the effect of using various absorbing materials on the productivity of a single-basin solar still. The materials used to enhance the absorptivity of water for solar radiation include dissolved salts, violet dye, and charcoal. The salts were potassium permanganate and potassium dichromate. They found that the addition of potassium permanganate resulted in $26 \%$ improvements in efficiency. The best result was obtained by using violet dye with an increase of about $29 \%$. Nafey et al. (2001) studied experimentally the use of black rubber or black gravel materials within a single sloped solar still as a storage medium to improve the still productivity. Solar still productivity enhancement using black rubber or black gravel. In later research, Tiris et al. (1996) examined the effects of using various different black-paint absorber materials on the thermal performance of a solar desalination unit. Also, Akash et al. (1998) studied the effect of using different absorbing materials in a solar still and thus enhanced the productivity of water. For example, using an absorbing black rubber mat increased the daily water productivity by $38 \%$. Using black ink increased it by $45 \%$. Black dye was the best absorbing material used in terms of water productivity. It resulted in an enhancement of about $60 \%$. El-Sebaii et al. (2000) designed and fabricated a single slope single basin solar still with aluminum movable baffle suspended absorber plate. The experimental and theoretical investigations were made by the suspended absorber plate with and without vents. The performance of the modified still was compared with the conventional solar still. The daily 
productivity of the modified solar still is increased from $4.736 \mathrm{~kg} / \mathrm{m}^{2} /$ day to $5.737 \mathrm{~kg} / \mathrm{m}^{2} /$ day compared to the conventional solar still.

El-Sebaii et al. (2009) studied the transient performance of a single slope single basin solar still integrated with stearic acid as a storage material beneath the basin liner of the still. They found that, on a summer day, the daily productivity of the still is found to be $9.005 \mathrm{~kg} \mathrm{~m}^{-2}$ day ${ }^{-1}$ with a daily efficiency of $84.3 \%$ on using $3.3 \mathrm{~cm}$ of stearic acid under the still absorber compared to $4.998 \mathrm{~kg} \mathrm{~m}^{-2}$ day $^{-1}$ when the still is used without the PCM. Naim and AbdelKawi (2002) used the solid material for energy storages in solar distillation. They examined the use of black gravel and charcoal bed of particles within a single slope solar still as a storage medium. They found that the charcoal particles and the black gravel have improved the productivity. While, Abu-Hijleh and Rababa (2003) reported that, the use of sponge cubes in the basin water resulted in a significant improvement in still production, up to $27 \%$. Where, the sponge cubes increase the surface area over which water evaporation occurs. The optimal combination was: sponge cubes with $6 \mathrm{~cm}$ sides, 20 $\%$ sponge to basin water volume ratio and $7 \mathrm{~cm}$ basin water depth. They found that, black colored material tends to be better than materials with other colors in absorbing the incident radiation. Arjunan1, et al. (2009) investigated the effect of energy storage medium on the productivity of the solar still. The performance of the still is evaluated through implementing the following effective parameters: (i) Conventional still and (ii) modified still (solar still with blue metal stones as storage medium). They concluded that the productivity of the solar still is increased by $5 \%$ when using blue metal stones as a storage medium. They also observed that the efficiency of the modified still is higher than the conventional still. Different types of absorbing materials were used by Abdallah, et al. (2009) to examine their effect on the yield of solar stills. These absorbing materials are of two types: coated and uncoated porous media (called metallic wiry sponges) and black volcanic rocks. The results showed that the uncoated sponge has the highest water collection during day time, followed by the black rocks and then coated metallic wiry sponges. On the other hand, the overall average gain in the collected distilled water taking into consideration the overnight water 
collections were $28 \%, 43 \%$ and $60 \%$ for coated and uncoated metallic wiry sponges and black rocks respectively. A concentrator-coupled hemispherical basin solar still with and without PCM has been investigated by Arunkumar, et al. (2013) to enhance the productivity. Experimental results indicated that the effect of thermal storage in the concentrator-coupled hemispherical basin solar still increases the productivity by $26 \%$. It was concluded that the productivity greatly increased due to the still integrated with PCM.

\section{Experimental setup}

The main objective of this research work is to study and examine the effect of granite basin in solar still productivity of fresh water and compare this basin with conventional basin. Two single sloped solar still was designed, installed and tested at the Agricultural Engineering Department, Faculty of Agriculture, Suez Canal University. Ismailia Governorate, Egypt (latitude angle of $30.62^{\circ} \mathrm{N}$, Longitude angle of 32.27 ${ }^{\circ} \mathrm{E}$, and mean altitude above the sea level of $5 \mathrm{~m}$ ). Two different solar still basins were designed and used during this research work. Each solar still basin is rectangular in shape and having gross dimensions of $130 \mathrm{~cm}$ long, $80 \mathrm{~cm}$ wide, and $10 \mathrm{~cm}$ deep with net surface area of $1.04 \mathrm{~m}^{2}$. A layer of $15 \mathrm{~mm}$ thick black granite is situated on the bottom of one still. The color of granite is permanent dark black so it will be better to absorb the maximum possible amount of solar radiation flux incident on it. The granite also has a smooth surface to make it easier to clean. In the basin there is no metal part so the problem of corrosion is avoided (Fig. 1). A very large part of the solar radiation, direct and diffuse, falling in the still is absorbed by the black basin. Small reflection losses occur by the glass surface due to its tilt angle. The energy absorbed at the basin is largely transferred to the water in the still and a small part of it lost to the surroundings by conduction, convection and radiation. The other basin of the second solar still is also rectangular in shape, $\left(1.04 \mathrm{~m}^{2}\right)$ and made of galvanized iron sheet. It is painted by red-lead primer then by matt-type black paint in order to maximize the absorbed solar radiation. The bottom frame was constructed of wood and insulated by a $2 \mathrm{~mm}$ thick of rock wool (thermal conductivity $=0.0346 \mathrm{Wm}^{-1} \mathrm{~K}^{-1}$ ) to reduce the heat lose. The outside walls were insulated with $7 \mathrm{~mm}$ thick foam (thermal 
conductivity $\left.=0.04 \mathrm{Wm}^{-1} \mathrm{~K}^{-1}\right)$. The solar still was covered with glass sheet ( $3 \mathrm{~mm}$ thick) with an inclination angle of $31^{\circ}$ to transmit the maximum possible of solar radiation flux incident on it. This inclination angle may be maximized the solar radiation flux incident. Moreover, with this inclined angle $\left(31^{\circ}\right)$ condensation will run down the underside into the trough rather than dropping from the cover into the basin. A trough running along the bottom side of the glass cover ensures the collection of the distilled water and leads it to the distilled watercollecting vessel and then measures by a graduated cylinder. The system has the capability to collect distillates from three sides of the still (i.e. the north, south and east sides). Rubber is used to prevent leakage from any gab between the glass cover and the still box. An inlet pipe is also fixed at the rear wall of the still for feeding brackish water as shown in Fig. (2).

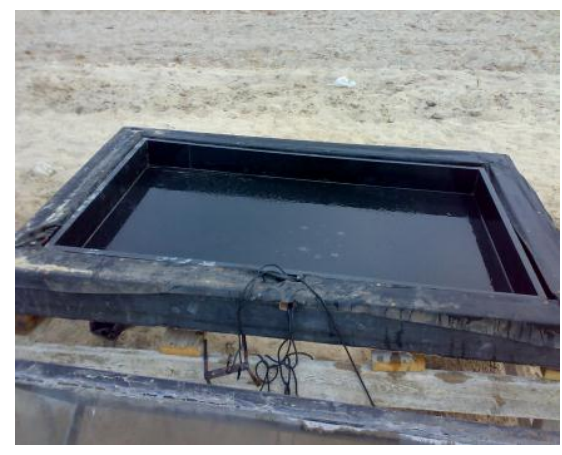

Fig. (1): Granite basin

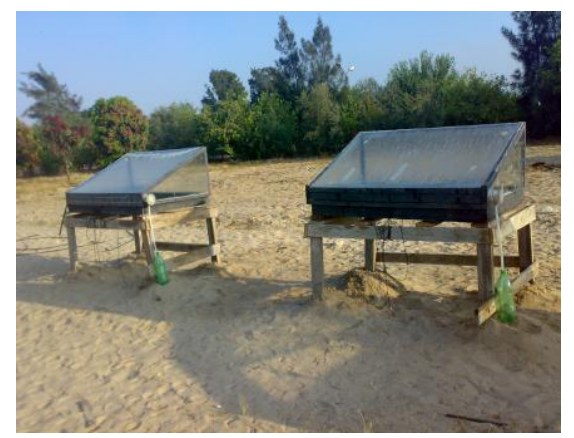

Fig. (2): Granite and galvanized iron basin stills

A solar cell $(75 \times 75 \mathrm{~mm}$, Kemo, 139, German made) was connected to a digital multimeter (M3800, China) to measure the solar radiation flux incident on the solar still according to Mujahid and Alamoud (1988). Calibration was carried out against an American made apply Pyranometer before the experimental work was executed. The short circuit reading obtained from the cell was converted into $\mathrm{W} / \mathrm{m}^{2}$ according to Duffie and Beckman (2006). Temperature of water, glass and vapor as well as the ambient air temperature were measured and recorded with the help of calibrated copper constantan thermocouples and a digital temperature indicator having accuracy of $0.1{ }^{\circ} \mathrm{C}$. The distillated fresh water was recorded with the help of a measuring cylinder. The hourly 
variation of solar intensity, water, glass, ambient temperatures and hourly output were recorded.

Experiment was carried out on successive days during the period of 2030 June 2014, the experiments started from 7:00 am in the morning to 6:00 pm in the afternoon.

\section{RESULTS AND DISCUSSION}

It is well known that the output of a solar still is strongly dependent on the solar radiation falling on and absorbed by the still basin. Fig. 3 depicts the solar radiation and ambient air temperature with respect to time. The measured solar radiation was in the range of $45 \mathrm{~W} / \mathrm{m}^{2}$ to 883 $\mathrm{W} / \mathrm{m}^{2}$ and the ambient air temperature was in the range of $25.4{ }^{\circ} \mathrm{C}$ to $34.9{ }^{\circ} \mathrm{C}$.

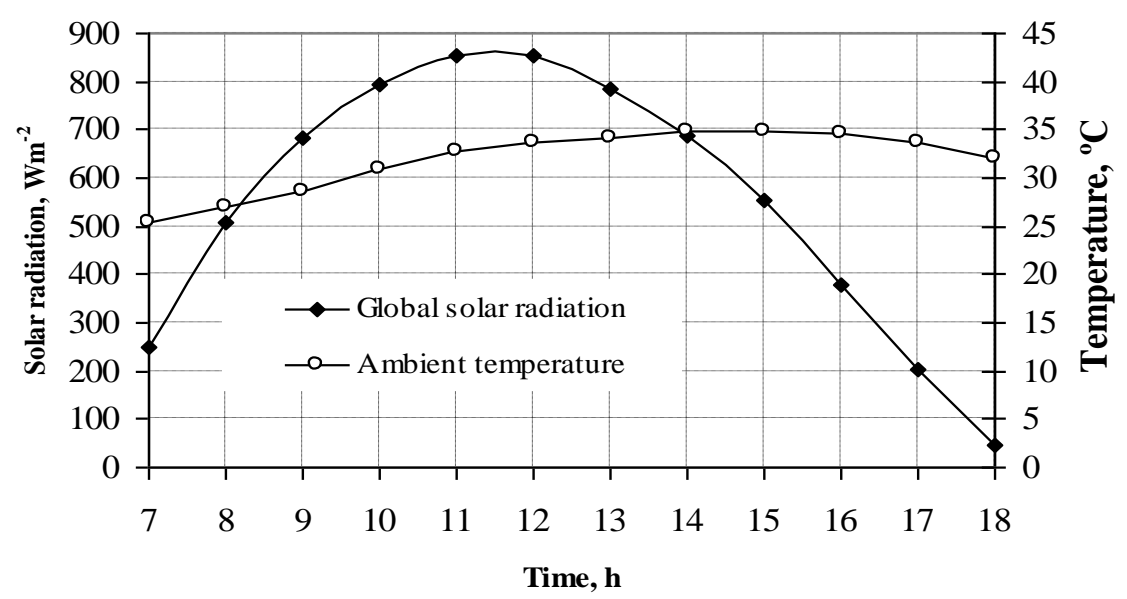

Fig. (3): Hourly variation of solar radiation intensity and ambient air as a function of the hour of the day

The temperatures of saline water in the two tested solar stills are shown in Fig. 4. It was observed that the temperatures at all points increase as the time increases till the maximum value achieved in the afternoon and start to decrease after that. This is due to the increase of solar radiation intensity in the morning and its decrease in the afternoon. It can be observed from Fig. 4 that, the maximum saline water temperature in the both stills is obtained at 13:00 hour. The water temperature was $30.3{ }^{\circ} \mathrm{C}$, $31.6{ }^{\circ} \mathrm{C}$ in the early morning and reached to $62.5{ }^{\circ} \mathrm{C}, 61.1{ }^{\circ} \mathrm{C}$ as a maximum saline water temperature for granite basin and galvanized iron basin stills, respectively. 


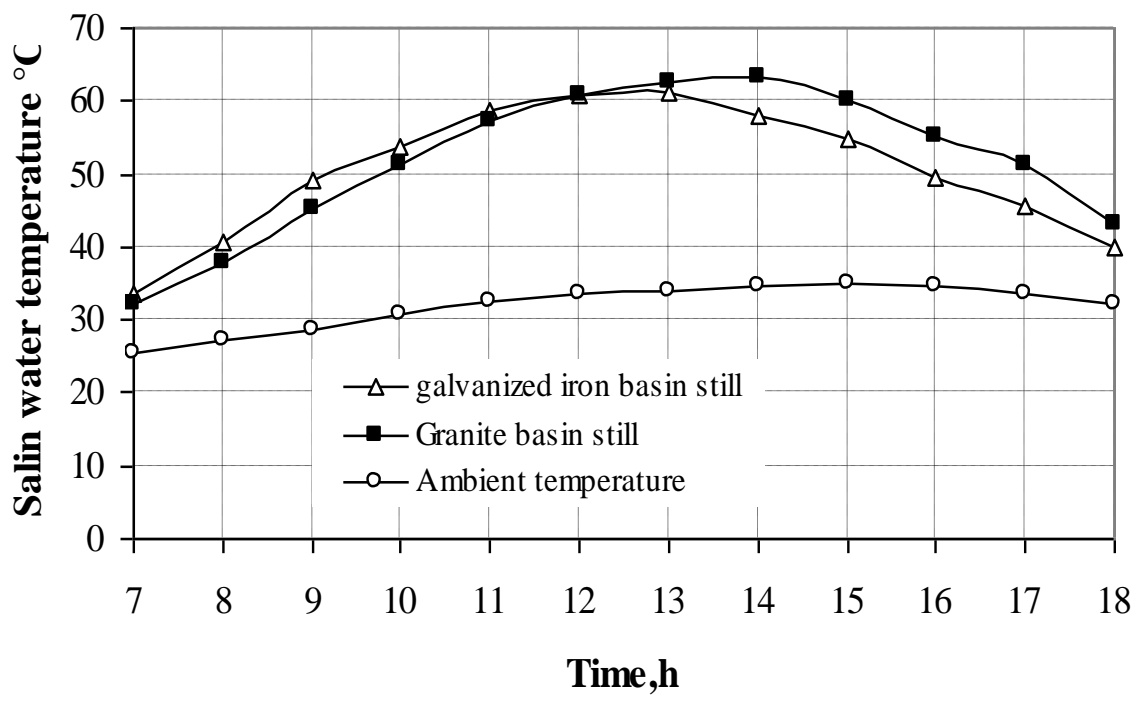

Fig. (4): Hourly variation of saline water temperature for single slope granite and galvanized iron basin stills as a function of solar time

Fig. 5 compares the variation of vapour temperature in the galvanized iron basin still and in the granite basin still. It was found that, the temperature of the vapor in the granite basin still is less than that of the metal still in the period from early morning to 12:00 hour.

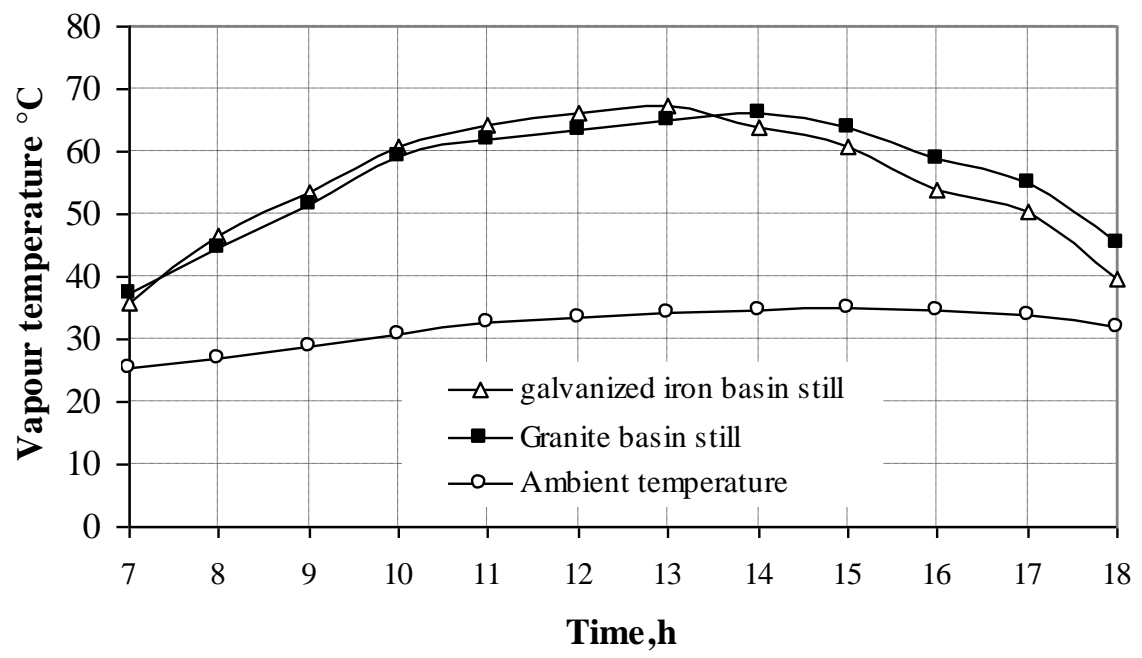

Fig. (5): Hourly variation of vapour temperature for single slope granite and $d$ iron basin stills as a function of the hour of the day 
During the period of $14.00 \mathrm{~h}$ to $17.00 \mathrm{~h}$ the vapour temperature in the granite basin still is higher than that of the galvanized iron basin still. The maximum value of vapour temperature was $67.3{ }^{\circ} \mathrm{C}$ and $66.2{ }^{\circ} \mathrm{C}$ for galvanized iron basin and granite basin stills, respectively.

Fig. 6 shows the inner glass temperature versus the solar time for the galvanized iron basin solar still and granite basin solar still. It can be seen that, the temperature of inner surface of glass cover increase continuously till reached the maximum value afternoon because the absorbed solar radiation exceed the losses to the surroundings. From about $2 \mathrm{pm}$., temperatures start to decreases due to the heat losses from the solar still which becomes larger than the absorbed solar radiation. The maximum value of this temperature was $58.4{ }^{\circ} \mathrm{C}$ and $58.1{ }^{\circ} \mathrm{C}$ for galvanized iron basin and granite basin stills, respectively.

It can be noted that the basin water temperature, vapour temperature and the temperature of inner surface of glass cover get closer to the each other because of the continuous contact between them which lead to heat equilibrium.

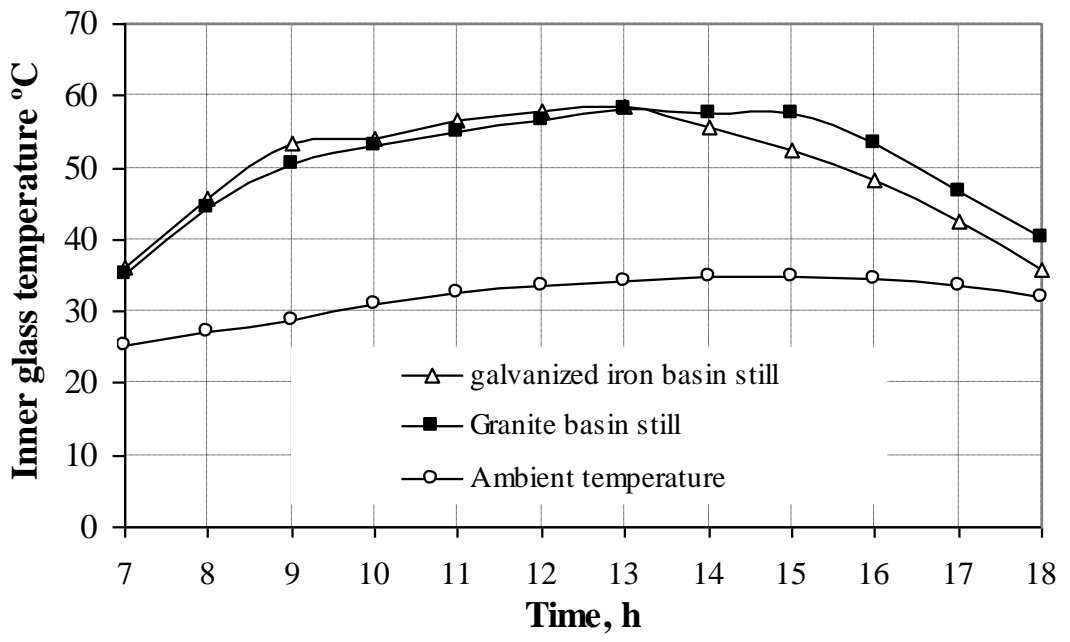

Fig. (6): Hourly variation of inner glass temperature for single slope granite and galvanized iron basin stills as a function of the hour of the day

Temperature variations of different components of the granite basin and galvanized iron basin stills are plotted in Figs 7 and 8. From these figures the temperature of vapour was higher than the temperature of the saline 
water and temperature of the inner cover. This is due to accumulation of latent heat of condensation released from the bottom of the glass cover and due to radiation loss from the water surface.

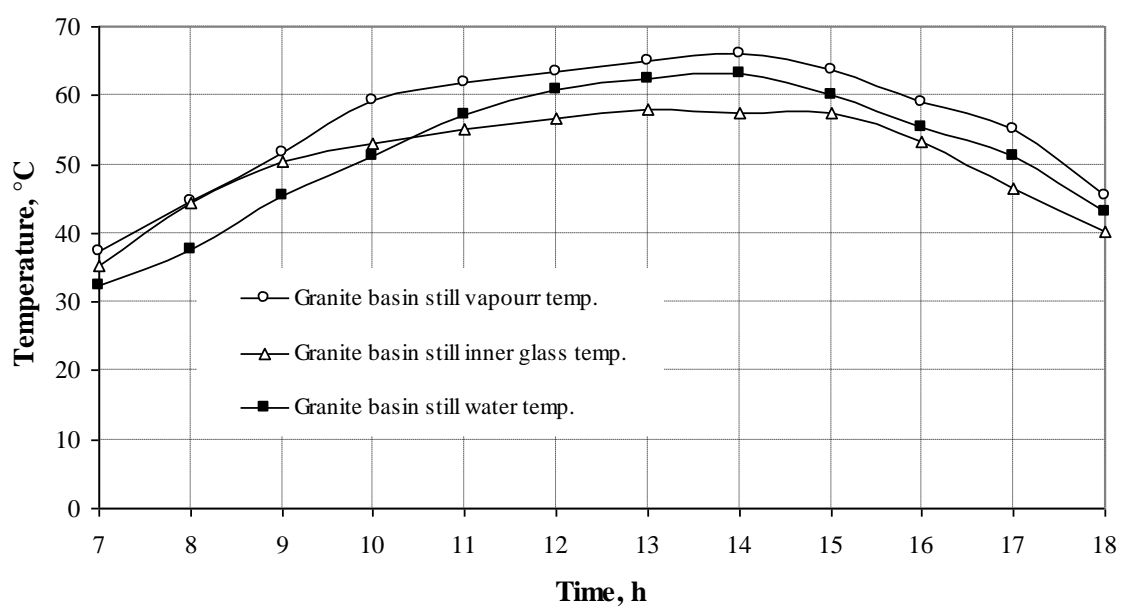

Fig. 7: Temperature variation of different components of the single slope granite basin still as a function of the hour of the day.

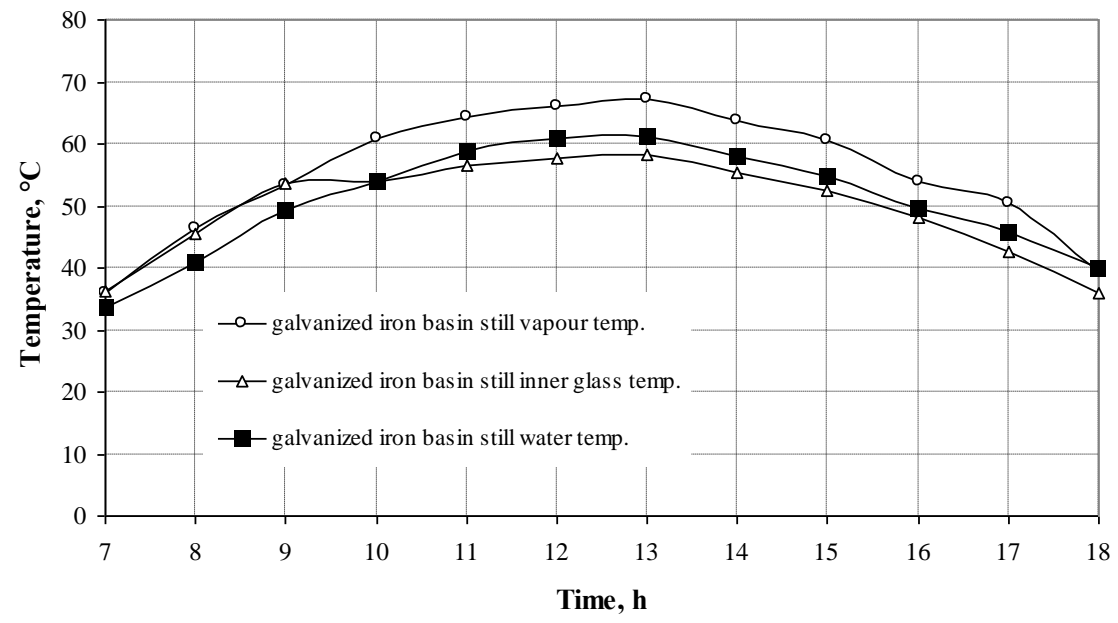

Fig. 8: Temperature variation of different components of the single slope galvanized iron basin still as a function of the hour of the day 
Fig. 9 shows the hourly variation of freshwater production for granite basin and galvanized iron basin stills. It clearly reveals that, the daily freshwater production increased gradually until reached maximum value at and around midday and then decreased in the afternoon, due to the variation in solar radiation intensity. The granite basin produced freshwater more than the galvanized iron basin still, this may be because of higher water temperature of granite still than galvanized iron basin still. The nocturnal production for each still is measured at 6:00 of the following morning and added to the day time production to obtain the daily production of both stills. The maximum productivity recorded was 141 and $170 \mathrm{ml}$ for galvanized iron basin and granite basin stills, respectively. The obtained results also show that, the productivity of granite basin still was $20.6 \%$ higher than the galvanized iron basin still. The shift in peak positions of the productivity for granite basin still towards late afternoon is probably related to that, part of the available heat is transferred and stored as a sensible heat within the granite basin and the higher amount of granite mass needs a larger amount of energy to rise its temperature and consequently take a longer time.

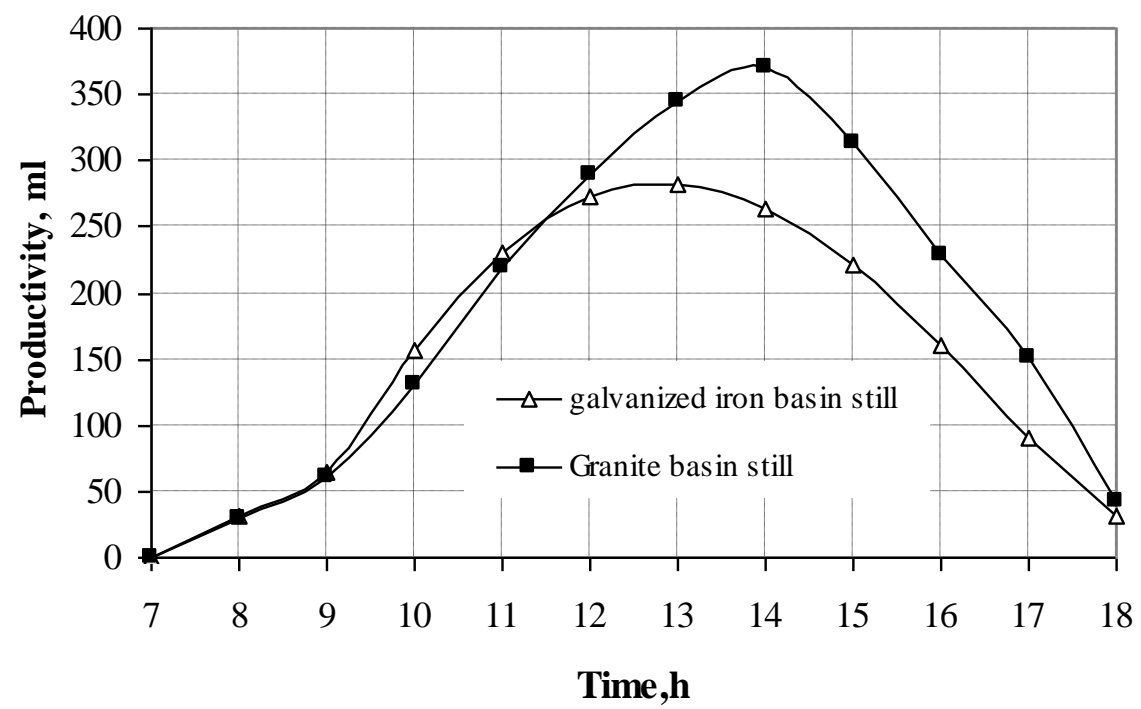

Fig. (9): Volumetric production rate for single slope granite and galvanized iron basin stills as a function of the hour of the day. 
Comparisons between the accumulative variations of fresh water productivity from 7:00 to 18:00 for the two tested stills are shown in Fig. 10. It is found that the cumulative still yield is 2181 and $1802 \mathrm{ml} \mathrm{m}^{-2}$ for the granite basin and galvanized iron basin stills, respectively. The cumulative yield of granite still is about $17 \%$ more than the metal still yield.

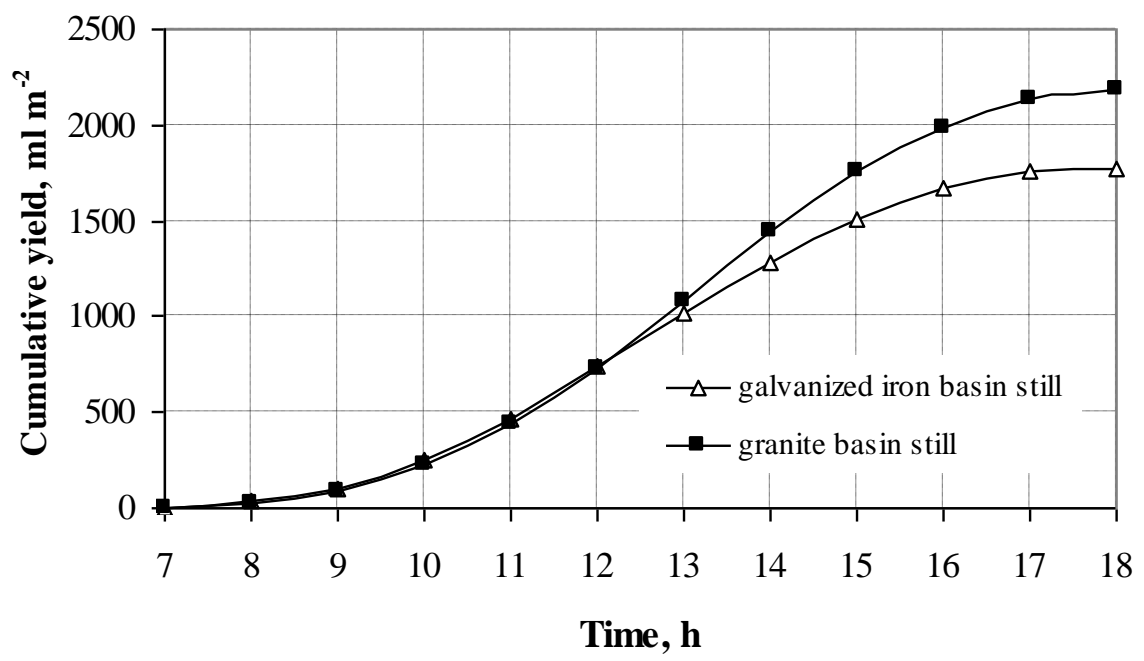

Fig. (10): Accumulative variations of fresh water productivity for single slope granite and galvanized iron basin stills as a function of the hour of the day

The hourly average thermal efficiency of the two tested stills is presented in Fig. 11. The results showed that the efficiency for the granite basin still was higher than the galvanized iron basin still. The daily average thermal efficiency of granite basin still and galvanized iron basin still was $27 \%$ and $20 \%$, respectively. The thermal efficiency of the two stills remains considerably high even during the end of the sunshine hours. This due to the water temperature in the still is high enough to drive condensation even at less solar irradiation. It can be also observed that the instantaneous thermal efficiency increases with time. After 16:00 $\mathrm{h}$. there was a sudden increasing in the efficiency of the granite basin still. This because of decreasing in solar intensity, while the evaporation rate of water remains constant due to heat capacity of the granite. 


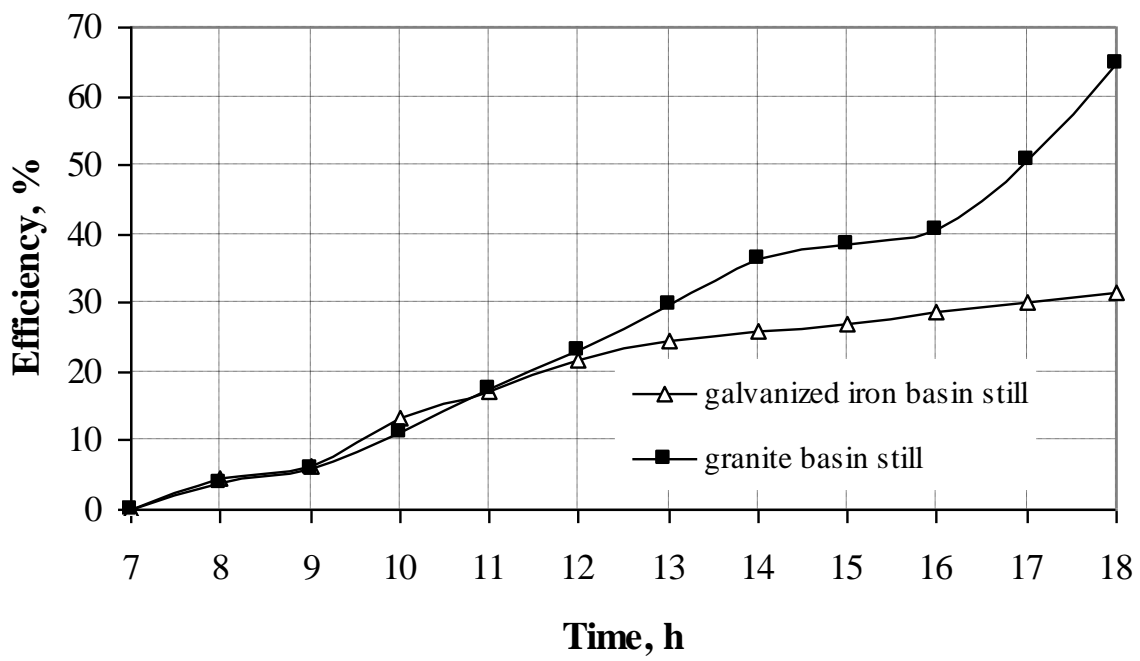

Fig. (11): Volumetric thermal efficiency for for single slope granite and galvanized iron basin stills as a function of the hour of the day

\section{CONCLUSION}

The conclusions that can be drawn from this study are as follows:-

1. An increase in still productivity was observed with the increase in ambient air temperature, solar intensity and increasing the temperature difference between glass and water

2. The granite basin still results in an increase in the productivity to about $21 \%$ more than the galvanized iron basin still

3. The efficiency for the granite basin still is higher than the galvanized iron basin still, and the daily efficiency of granite basin and galvanized iron basin stills was $27 \%$ and $20 \%$ respectively.

4. The granite basin have the ability to absorb and store the radiation as heat during sunshine hours, and then release the stored energy slowly to the water in the low intensity hours.

\section{REFERENCES}

Abdallah, S.; Abu-Khader, M. and Badran, O. (2009): Effect of various absorbing materials on the thermal performance of solar stills, Desalination 242, 128-137

Abu-Hijleh, B. and Rababa, H. (2003): Experimental study of a solar still with sponge cubes in basin, Energy Conversion and Management, 44(9): 1411-1418. 
Akash, B. A.; Mohsen, M.S.; Osta, O. and Elayan, Y. (1998): Experimental evaluation of a single-basin solar still using different absorbing materials, Renewable Energy, 14, 307-310.

Arjunan1, T.V.; Aybar, H.S.; Nedunchezhian, N. and Sakthivel, M. (2009): Effect of Blue Metal Stones on the Performance of a Conventional Solar Still, Journal of Convergence in Engineering, Technology and Science, 1, 17-22

Arunkumar, T.; Denkenberger, D.; Ahsan, A. and Jayaprakash, R. (2013): The augmentation of distillate yield by using concentrator coupled solar still with phase change material. Desalination, 314, 189-192

Duffie, J. A. and Beckman, W. A. (2006): "Solar Engineering of Thermal Processes" New York, N.Y., John Wiley and Sons.

El-Sebaii, A. A.; Aboul-Enein, S. and El-Bialy, E. (2000): Single basin solar still with baffle suspended absorber .Energy Conversion and Management, 41(7): 661-75.

El-Sebaii, A. A.; Al-Ghamdi, A. A.; Al-Hazmi, F. S. and Faidah, A. S. (2009): Thermal performance of a single basin solar still with PCM as a storage medium. Applied Energy, 86, 1187-1195

Mujahid, A. M.; and Alamoud, A. R. M. (1988) "An easily designed and constructed photovoltaic pyrheliometer" Solar \&Wind Technology, 5 2, 127-130

Nafey A. S.; Abdelkader, M.; Abdelmotalip, A. and Mabrouk, A. (2001): Solar still Productivity enhancement. Energy Conversin and Management, 42, 1401-1408,

Naim, M. and AbdelKawi, M. A. (2002): Non-conventional solar stills. Part 1. Non-conventional solar stills with charcoal particles as absorber medium. Desalination, 153, 55-64.

Nijmeh. S.; Odeh, S. and Akash, B. (2005): Experimental and theoretical study of a single-basin solar still in Jordan, Int. comm. Heat Mass Transfer, 32, 565-572.

Tiris, C.; Tiris, M. and Türe, I. E. (1996): Improvement of basin type solar still performance: Use of various absorber materials and solar collector integration, Renewable Energy, 9, 758-761. 
Tiwari G. N (2003): Solar energy: fundamentals, design, modeling and application, New York/New Delhi: CRC Press/Narosa Publishing House.

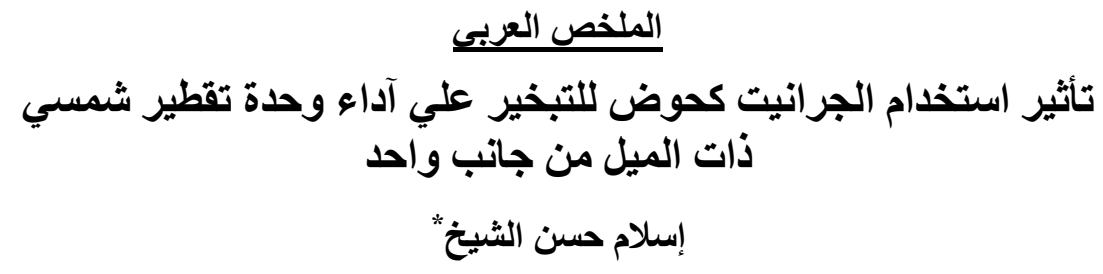

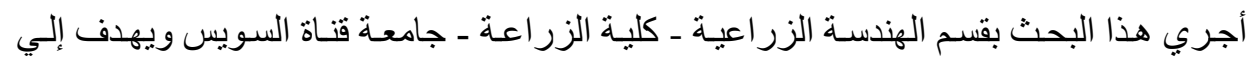

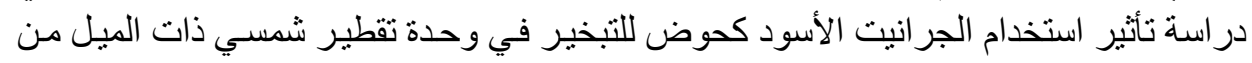

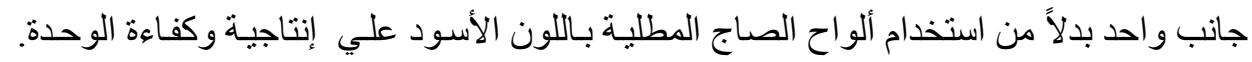

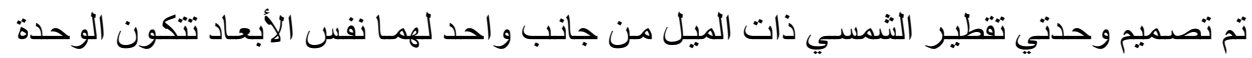

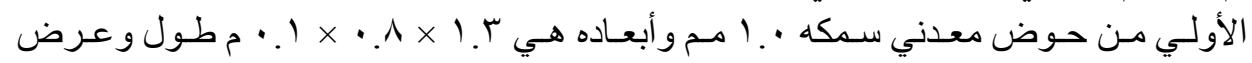

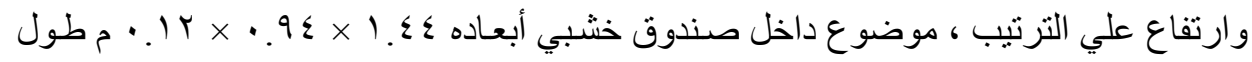

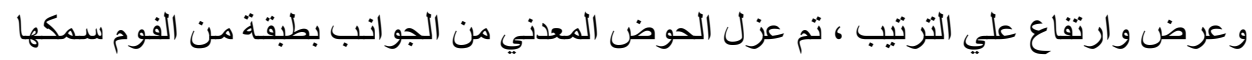

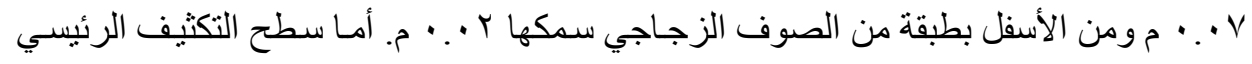

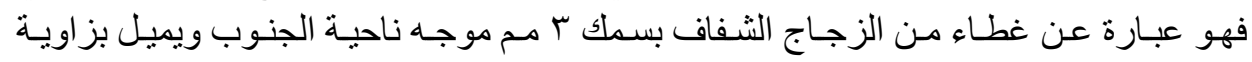

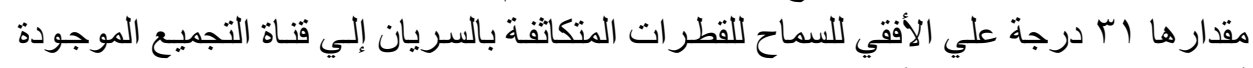

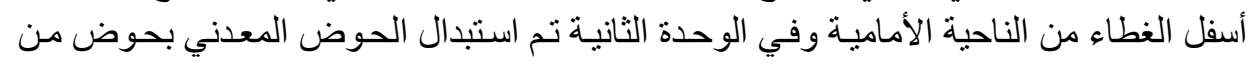

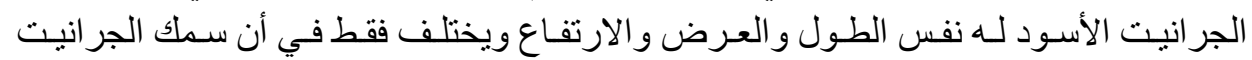

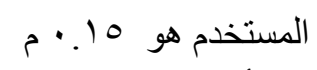

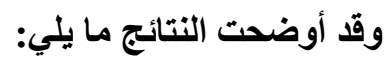

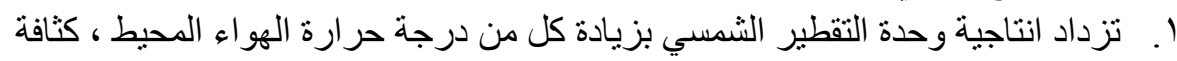

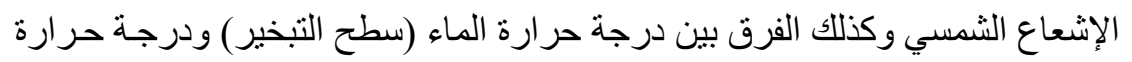
السطح الداخلي للزجاج (سطح التكثيف).

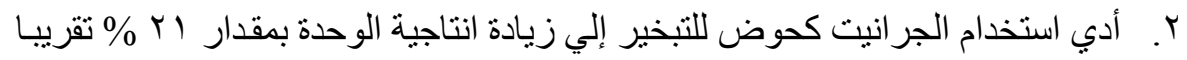
عند مقارنتها بالوحدة التقليدية

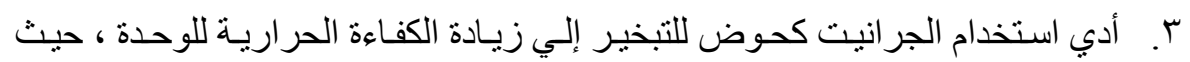

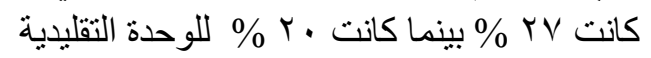

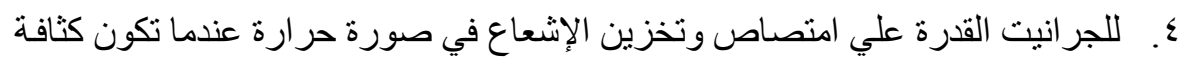

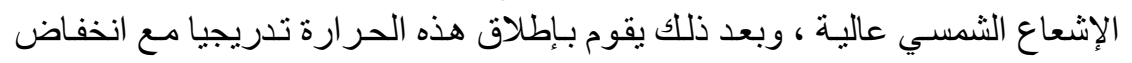
كثافة الإشعاع.

" أستاذ مساعد ـ قسم الهندسة الزراعية ـ كلية الزراعة ـ جامعة قناة السويس * 